\title{
Investigating Some Cases on Executive Immunity of States
}

\author{
Keyvan Daryabeigi Balvardi ${ }^{1}$ \\ ${ }^{1} \mathrm{MA}$ of International Economic Commercial Law, Tehran University, Kish International Campus, Kish, Iran \\ Correspondence: Keyvan Daryabeigi Balvardi, MA of International Economic Commercial Law, Tehran \\ University, Kish International Campus, Kish, Iran. E-mail: keyvandaryabeigi@yahoo.com
}

Received: May 1, 2017 Accepted: May 23, $2017 \quad$ Online Published: June 1, 2017

doi:10.5539/jpl.v10n3p158

URL: https://doi.org/10.5539/jpl.v10n3p158

\begin{abstract}
Immunity from execution means that the criminal court verdict against a natural person who is resident in the country as a foreign government's representative is not enforceable. Its philosophy is the good performance of diplomatic missions and compliance with the general principle of the sovereignty of states whereby no state should be judged by another state or another state's laws are applied to it. Despite some views that under certain circumstances and with certain existential context continue to invoke the immunity, there is no doubt that the dominant approach of courts in civilized societies is to accept the immunity of property and governing activities of states and to reject their immunity about their possessive properties and activities. Here we review some proceedings which can clearly demonstrate through argumentative and legal bases that the sovereignty of the politics over the law and justice is already over.

The following cases will be examined in this study: Swiss company NOGA vs. Russian Federation, the US company Creighton vs. the State of Qatar, Swiss company Ektimon vs. the Government of the Socialist Republic of Libya, and the Central Bank of Iran vs. Peterson.
\end{abstract}

Keywords: immunity from execution, government, the Company NOGA, Company Creighton, Company Ekitmon, the Central Bank of Iran

\section{Immunity from Execution}

In public international law, in order to safeguard diplomatic and consular tasks, a privilege has been granted to foreign government and its diplomatic and consular representatives that is called immunity. Immunity from execution means that the criminal court verdict against a natural person who is resident in the country as a foreign government's representative is not enforceable. The same applies to foreign government property and assets of the individual representing the foreign government. In other words, under the theory of immunity property, life and dignity of representatives of a foreign state are not under the rule of the host state. In case of violation, they will be prosecuted in their home country. This type of immunity faces with different approaches in terms of government power but is accepted by the public and its philosophy is the good performance of diplomatic missions and complying with the general principle of the sovereignty of states, whereby no state should be prosecuted by another state or laws of another government are applied to it.

\section{NOGA (Switzerland) - Russia}

The first case to be studied is the dispute between the Swiss company NOGA and the Government of the Russian Federation. The Russian government has taken several loans and failed to pay for them, according to former contractual agreement referring to taking the dispute to the arbitration, it has been sentenced in 2 arbitration award to pay a total of more than $\$ 50$ million and in order to secure the sum, Russian state and embassy's assets has been seized in France. Swiss company argued that according to a clause in the contract between the company and the Russian government, disputes will be referred to arbitration and the borrower (Russia) denies all immunities related to hearings and execution of votes.

Following this strong argument, the Court of First Instance of Paris investigates the arbitration award on 11 July 2000 and does not order the enforcement of arbitration award. Derogation of the Russian state from its executive immunity in the contract is so clear that has left no place for hesitation in judicial proceedings and primary arbitration and bank accounts of the Russian government and its embassy were seized in France in order to pay 50 million dollars as compensation. Approach of the Russian government at this stage seems wrong because despite other things to reverse arbitration award and despite its reiteration to waive immunity in the original 
contract, it continued to invoke its immunity and cancellation of the clause in the contract. Of course, the result of this wrong approach was the losing of primitive stage.

In the appeal court, the court argued that the Russian government has not clearly derogate from the rights in the contract and according to many international principles such as Diplomatic Relations Vienna Convention (1961), such seizure is inadmissible. This approach seems very strange because even in the French procedure much lower than this expression is acceptable. The Court also could not reached the derogation from immunity using the term "borrower denies all rights to immunity from itself" and ordered the removal of the seizure. Of course, this approach has a strong argumentative base that justifies the decision should not to accept the legitimacy of the seizure of state property. The Court expressed that the property was not of commercial nature and was of governmental, national, and diplomatic one. So, the Swiss company have to provide reason for this allegation. It seems this part of the reasoning of the Court of Appeal in France has compensated the primary weakness and clearly expressed the ban on the diplomatic and governmental assets; however, the party claims such property is commercial.

\section{Creighton (United States) - Qatar}

The second case is the contract between the American company Creighton and the State of Qatar to build an equipped hospital in Doha.

Creighton Company implemented the contract and after refusal of payment of committed funds by the government of Qatar, it enters into the arbitration process. Under the arbitration sessions (the procedure of the contract accepted by the parties in order to resolve upcoming disputes) a total of 3 votes issued against the State of Qatar and subsequently the order issued to seize assets associated with bank accounts of Qatar in National Bank of Qatar and Bank of France.

Given the seriousness of this dispute and arising the case in the courts of France and citing executive immunity by the State of Qatar, the Court of Appeal in Paris in July 1998 ordered the prohibition of the seizure of the seized bank accounts. The court reasoned that:

Firstly- the derogation of the government from its immunity has not been established.

Secondly- the issue of commercial property is also not clear. This was seriously criticized by doctrine and the appeal court reversed the verdict. French appeal court said in its decision that although the Court of Appeal correctly stated that the mere acceptance of the arbitration agreement cannot be considered as a derogation from immunity and given that the rules governing the arbitration process have been compiled with ICC Arbitration rules and given that in the provisions both parties are committed to rapid implementation of the arbitration award, it can be considered the selection of the Regulation of the ICC as the unconditional acceptance of the award and its implementation. In fact, the French appeal court referring to Article 24 of ICC rules issued the verdict. In addition, the Court about the commercial nature of an asset stated that assets kept in commercial bank accounts can be seized. Because they are considered as assets with lack of immunity and are assumed as commercial property.

Given the reasoning of the court of appeal in France for the observed dispute between Creighton and the State of Qatar, it can be understood that:

Firstly- to sign the arbitration clause does not mean the derogation from the state executive immunity and it needs explicit or implicit stipulation. Example of explicit stipulation is like in one of the provisions of the original agreement the foreign government committed to the implementation of the arbitration and/or derogated explicitly from its commercial property. An example of implicit stipulation is to accept provisions of the ICC (and more specifically Article 24) and or any other regulation that its implementation is subjected to the acceptance of restrictions on the immunity of state property.

Secondly- it should be considered the nature of bank accounts and assets in another country. If the seized assets is to meet jointly the needs of government and enterprise, they are subjected to be seized, just like when all those bank accounts, properties and funds of the arbitration award are dedicated to commercial affairs. The only loophole in this case is that the sized assets should be used merely for the government affairs. In this case, it restores the state executive immunity.

Given the 2 verdicts, it can be understood that:

A) There is the possibility of derogation from the immunity stipulating in the contract if the stipulation is explicit and clear and it logically calls to the mind the acceptance of the implementation of the arbitration award. As in the acceptance of the condition of ICC addressing the immediate implementation of the arbitration award 
in the primary court (Creighton - Qatar) and also expressing to waive immunity in the second hearing (Russia NOGA). In fact, it seems in the lack of clear rules for the definition of explicit derogation from executive immunity, it depends on the conscience of judges whether the immunity derogated in contracts.

B) If state properties are specified as governmental affairs, they cannot be seized even with the acceptance of the offending government and its derogation from immunity. In fact, state property cannot be seized naturally.

The property can be seized, if it is allocated to commercial affairs, even if this property is partially dedicated to commercial and possessive affairs.

B) Proving whether the accounts and assets of a foreign state are commercial is a different procedure. If the seized property are of commercial nature (such as food companies, pharmaceutical companies, bank accounts related to the activities of the possessive activities and etc.), it is up to court and/or any of the parties to prove their commercial nature.

If the issue is of governmental nature (e.g. embassy, bank accounts or property related to the embassy support affairs and/or central bank), proving that the account is for possessive affairs and thus its immunity derogation is up to the plaintiff of the seizure. It seems that still courts are not interested in gaining reason in favor of the private party against a foreign government; however, if chosen, they will vote for it.

\section{Ekitmon (Switzerland) - Libya}

\section{Case of Libya - Ekitmon:}

Another important case concerning the executive immunity of the state is the case of the Swiss company Ekitmon vs. the Government of the Socialist Republic of Libya. What makes the adopted legal approach and proceeding very important in this case is the issue of impunity or lack of the immunity of the central bank assets. In other words, there is always a strong belief that the central bank assets may not be seized and the Swiss Federal Court's reasoning is a farther try to limit the immunity of state property that can help to establish justice.

The Swiss company in 1980 in a contract of 10 million Francs (Swiss Franc) was committed to establish, set up and equip a dairy unit in the city of Fatij in Libya. During the implementation of these commitments and following the systemic problems in Libyan economy and refusal of the host government of fulfilling some previous agreements, serious disputes arose among the parties. So, only four years after signing the contract, the Swiss company brings the case to the court of First Instance of Switzerland in Zurich and apprizes its losses 460 thousand Francs. Providing evidence over the violation of Libyan state, it demands the seizure of part of the Libyan state assets in Switzerland. The company Ekitmon intended to seize assets of the National Oil Company of Libya and the Libyan Central Bank. In the end, the District Court of Zurich under an interim order accepted the seizure of the assets of the Libyan oil company but rejected the seizure of the assets of the Central Bank. The reason for this Court to discriminate between the property of the central bank and the Libya's National Oil Company is that oil exports in nature is a possessive activity and is out of the verdict but central bank assets are dedicated to the governmental affairs and management of the community and so it cannot be seized. Following this decision, the victim attempted to appeal the decision in the Supreme Court of the Canton. Ekitmon explains that not all of the Central Bank assets in Switzerland is for sovereignty affairs and these assets are also dedicated to matters such as commercial and industrial contracts. The court accepted the company's argument and ordered the confiscation of part of the assets of the Central Bank of Libya and send the case to the Court of First Instance to issue a seizure warrant.

The Court of First Instance also immediately seized some of the promissory notes issued by the World Bank IBRD for Central Bank of Libya (deposited in the Swiss National Bank) as part of central bank assets which is worth more than 2 times as the amount apprized by plaintiff. It also did not remain without opposition and the government of Libya appealed against the interim order. Libyan government said that assets of the central bank cannot be seized under international law and the confiscation of the assets hits the sovereignty of the country. The dispute led to the Swiss Federal Court. The Court was faced with two important questions:

-Does the Libyan government have the right to appeal against the injunction?

- Is it unconditionally not possible to seize the assets of the Central Bank of Libya?

In response to these uncertainties, the Swiss Federal Court declared that the Libyan government has the right to appeal against the issued injunction and it can be heard. However, there are serious doubts about not enforcing the verdict against the Central Bank of Libya and the seizure of its assets.

Federal Court of Switzerland, as the ruling authority, stated that there is no state immunity convention between Libya and the state of residence of the court i.e. Switzerland. As a result, the principles of international law and 
internal regulations of Switzerland would govern this dispute. Doctrine of the immunity and jurisprudence of Switzerland in this regard is on the basis of limited immunity not absolute one. In Swiss law (as seen above) the limit of immunity is based on whether contract activity and seized property are governmental. Federal Court argued that seized securities can hardly be attributed to the general sovereignty of Libya and it seems that its possessive aspect is strong. In fact, the court correctly believes that not necessarily all of the assets of the central bank are governmental because some of these acts are done with the aim of gaining profit.

It is necessary to point it out that in dealing with the separation of commercial affairs from governmental ones there are three different approaches taken by legal systems. Some of these systems, such as the United States of America puts the base of the separation on the nature of the acts and recognize those acts as governmental that the private sector does not do them. Some other legal systems considered the target of the property and point out that the base of the separation is the aim i.e. whether the purpose of this activity is profit. There is a third hybrid approach that Canada is its founder. This approach considers both the purpose and nature as the necessary conditions and in fact it does not consider the mere profitability or exclusiveness of the activity as enough. Swiss Federal Tribunal in this regard was subjected to the recent composition.

And also there is no prohibition for the private sector to participate in these activities (for example launching a Dairy company).

Observing failure in this part, Libyan government lawyers considered another argument. The group stated that the central bank has a legal personality independent from the government and the Central Bank of Libya is not an exception. The management of Libyan central bank is independent from the Libyan government and its task is the maintenance of order and mintage aiming to provide the value of its currency and credit. Thus, the seizure of an independent person's assets for violation of another person lacks legal grounds. The court dealing with the case said that if the Libyan government had been independent from the central bank, cancelation of the seizure of the Central Bank of Libya must have been done by the bank and not the Libyan government. The paradox resulting in the rejection of the recent argument of the Libyan government. In response to the claim that these accounts are governmental, the Court stated that some parts of the assets of the central bank cannot be seized. However, it considered the securities in the list of assets that can be allocated to commercial activities as well as national and governmental affairs. Finally, the securities were seized to pay the loss of the company Ekitmon.

Despite the fact that the arbitration was not involved in the case, it is important due to the denial of the immunity of the central bank. Libyan government by transferring its commercial assets to governmental accounts wanted them to be immune from enforcement action but courts in modern legal systems were not deceived by these measures and it can be said that the result of the violation of commitments and transferring commercial assets to national accounts is nothing but the confiscation of the more vital assets of the country and the judicial approach is certainly applicable to the arbitration. Discriminating the state property, today in many arbitral decisions the part related to the commercial affairs will be seized.

\section{The case of the Central Bank of Iran - Patterson}

The story of this case which is open in the time of writing of this research is that in 2007 one thousand US families from victims of the 1983 military base of US Marine in Beirut took the case to the judiciary of America and called for their physical and mental losses (apprized \$ 2 billion) from Iranian government assets in the United States as compensation to the victims of the event. A court in New York ruled the seizure of the property of the Central Bank of Iran and Iran appealed against the verdict. At the same time, while Iranian assets including dollar securities of the Central Bank is in the account of CT Bank of New York, US Court of Appeals in New York rules that the property can be used as compensation to the families of the victims of the event. Finally, the property seized in the year 2008 (1387).

The Central Bank of the Islamic Republic of Iran at this stage of the proceedings relating to the enforcement appeal against this practice. It provided its reasons to the illegal seizure of their assets even justifiable on the basis of US law. One of the arguments of the bank was that the Central Bank of the Islamic Republic of Iran is independent from the government and votes against the government and other institutions cannot be applied against the Central Bank (Argument used by the Libyan government earlier in the case of Ekitmon in a relatively similar process and legally was not able to work).

Iran's central bank also announced that it has immunity and the immunity has been recognized in the US and foreign governments' immunity law.

Presentation of the argument from the legal officer of the Central Bank was provided as the United States in 1996 had amended the immunity law of foreign states (enacted in 1976). According to this law, US persons 
affected by the attacks anywhere in the world or the survivors of the attacks can complain in American courts against governments that this country claims that they are pro-terrorist.

Anti-terrorism law of 2001 in America in section four hundred and three cites the property to be seized unconditionally in case of involvement in terrorist activities as follows: All assets, foreign or domestic of any person, entity or organization engaged in planning or perpetrating any act of domestic terrorism or international terrorism against the United States, citizens or residents of the United States, or their property, and all assets, foreign or domestic, affording any person a source of influence over any such entity or organization; acquired or maintained by any person for the purpose of supporting, planning, conducting, or concealing an act of domestic terrorism or international terrorism against the United States, citizens or residents of the United States, or their property; or derived from, involved in, or used or intended to be used to commit any act of domestic terrorism or international terrorism against the United States, citizens or residents of the United States, or their property.

In The United States of America, the State Department is responsible for publishing the list of states that sponsor terrorism. Iran has been on the list since 1984 .

The central bank provided a petition in the US Supreme Court asking the Court to declare that the law in in conflict with the American constitution. The Central Bank of Iran argues the principal of the separation of powers in the constitution of the United States. Accordingly, Congress cannot pass a law related to a case that is under investigation in the court.

The legal dispute in the preliminary stage continued to 2012 and it seemed to have everything against Iran and apparently any legal action and even diplomacy failed to prevent the ruling and finally the final verdict of the Supreme Court of America finalized against Iran.

The verdict and its judicial process in several ways is seriously debatable. It seems that contrary to earlier verdicts, in the case there are legal innovations that some appear to be inadmissible. According to the subject of the study, we will discuss the seizure of the assets of the Central Bank of Iran.

Lower court decision was issued in 2008. Central Bank of the Islamic Republic of Iran objected to the verdict and the proceedings in the Court of First Instance continued until 2012. Congress of the United States of America in 2012 changed the law governing the subject, after which the lower court ruled in accordance with the law and the appeals court upheld it. The Central Bank of Iran demanded in a petition from the Supreme Court of America to declare that the law is inconsistent with the constitution of the United States. Iran also argues that according to the principle of separation of powers in the United States, the US Congress cannot pass a law about a case being handled in the courts of that country. However, contrary to expectations of Iran, Supreme Court of Appeal confirmed the lower court verdict. So, the verdict virtually made it possible to seize and divide the assets of the Central Bank of Iran.

It's not like that in the course of the investigation there is no failure from the Iranian side and at least in some cases it seems there was also the possibility of a more deliberate measures. One of these measures was exiting certain assets available to the central bank from the United States or disputed accounts. Not exiting the property, given the starting of the process of financial and banking sanctions in 2006 which was fully expected to lead to central bank sanctions, was a clear recklessness. Also, not exiting the property from US by the authorities of the time before 1387 due to the efforts of "companions of Peterson case" which highly sought for Iranian funds to seize was another recklessness.

This failure can also be found in the documents listed in the United States Supreme Court in "History of assets and other documents related to the assets of the Iranian central bank" and some of these reports confirm it. According to the judicial body, since the beginning of 2008 onwards, assets of the Central Bank of Iran has been in Citibank of New York as securities. This property was controlled and managed directly by the brokerage of the company "Clear Stream" stationed in Luxembourg. The company is specialized in acting as intermediary between financial institutions around the world. Clear stream put the central bank assets and profits derived from bonds into its account at the Company. In 2008, the central bank ordered the company to establish another account in an Italian bank. The company deposited the profits in the UBAE account of the bank which was then paid to the Central Bank. Disregarding for such reports that implies the attention of Peterson plaintiffs, was the reason for continuing problems related to the seizure, because over the years there was no serious action to sell these securities and transfer the money to another place.

Of course, criticism is also aimed at linking the seized property to the deal of Western governments and the Islamic Republic of Iran and the release of frozen assets of Iran in US in the framework of the joint comprehensive plan of action (JCPA) between the two groups of countries (Iran, on the one hand and five 
nuclear powers such as France, United States of America, Britain, Russia and China as well as Germany on the other hand); but are free of legal charge, because this verdict has already been confirmed and issuance came to years ago.

Another negligence is in the way that the immunity of Iranian state is referred to. As previously stated, for invoking immunity, there should be no expression of the will or consensus even implicit one about the government acceptance in the prosecution and arbitration and in such case if the court understands the arrival of government to the case, it will abolish the immunity. Hiring a lawyer and appealing in the court of America was another action by Iran that legally approved the competence of the American Court and virtually lost next citation to this immunity. But we should not forget no one of these drawbacks justifies partiality and political approach of America's Supreme Court. As previously repeatedly referred to, the central bank assets are immune from enforcement and seizure because there is the assumption of sovereignty here and its obligation is to advance non-commercial purposes unless in circumstances (such as Ekitmon case) the commerciality of a certain part of the property of the central bank be established and court finds out that the property is non-governmental; however, this was not observed in the seizure of Iranian assets. In Article 1611 of Foreign States Immunity Act in the United States, central banks are independent from governments. However, lawyer of the claimants of the Peterson case in his bill argues that Iran's central bank is under government's control and has no independence citing some of the speeches and actions of former heads of the Iran. The bill of Plaintiffs' lawyers stressed that however the central bank is apparently based on banking and monetary law, the assets held in the name of the central bank are mostly owned by the government and government dictates its orders to central bank through the appointment of officials and controlling central bank operations. The bill cites several cases of what is called interference and lack of independence of the Central Bank of Iran. However, it does not seem to be legally justified to confiscate the property of the Central Bank of Iran.

Another point is that according to Articles 27 and 46 of the Treaty of 1969 Vienna on the Law of Treaties, the United States government and no other states can apply their own rules as pretext to violate its international obligations and without a doubt cancelation of the seizure of a foreign central bank assets is an international commitment for the government of the United States. As a result, these confiscation of assets is unjustified and contrary to the spirit of international law and various legal and judicial procedures of other progressive governments in the world.

\section{Conclusion}

In public international law in order to safeguard diplomatic and consular tasks, some privileges are given to a foreign government and its diplomatic and consular representatives which is called immunity. Immunity from execution means that the criminal court verdict against a natural person who is resident in the country as a foreign government's representative is not enforceable. The same applies to foreign government property and assets of real person representing foreign government in the country. In other words, under the theory of immunity, property, lives and dignity of representatives of a foreign state are not under the rule of the host state and in case of violation they will be prosecuted in their home country. Although this type of immunity has faced with different approaches in the enforcement in terms of government power, it has been accepted by the public. Its philosophy is the good performance of diplomatic missions and compliance with the general principle of the sovereignty of states whereby no state should be judged by another state or another state's laws are applied to it. In order to remove the executive immunity of state or its functional units and to go out of the impasse of the enforcement of the verdict, the explicit withdrawal of immunity from execution should be inserted in the contract. So, if the investment of the foreign private person is important for the government, he may be able to convince the government that in addition to accepting the arbitration, the host state waive any right to sovereign immunity for itself and its property in the implementation of the arbitration award. However, in practice it is very unlikely that the choice will be accepted by the host government due to the importance and sensitivity of government sovereignty.

If the verdict is against the government, the government can invoke the principle of its executive immunity and create effective barrier in the way of enforcement of the verdict and according to the laws of the contracting states about executive immunity, it can make it impossible to cross the barrier. However, it must be noted that the issues of executive immunity are not isolated and separated from other provisions of the Convention and it considers within the whole. However, the condemned state makes the enforcement of the verdict ineffective in its court or the courts of other Contracting State resorting to its executive immunity.

\section{References}

1969 Vienna Convention. 
Bank Markazi v. Peterson -US Supreme Court Decision No.14-770, April 2016.

Emmanuel Gaillard recent developments in state immunity from execution in France: Creighton v. Qatar 1998.

International law reports Vol, 82. p 30.

Iran Threat. Reduction and Syria Human Rights Act of 2012.

NOGA v. federation of Russia MEALEY'S international arbitration report- Oct 2000-- Vol 15.

The Iran and Libya Sanctions Act of 1996 (ILSA).

\section{Copyrights}

Copyright for this article is retained by the author(s), with first publication rights granted to the journal.

This is an open-access article distributed under the terms and conditions of the Creative Commons Attribution license (http://creativecommons.org/licenses/by/4.0/). 